\title{
Assessment of heavy metals in the surrounding soils and their bioconcentrations in few plants near Kathajodi river, Odisha, India
}

\author{
S. R. Barik ${ }^{1}$, P. J. Mishra ${ }^{2}$, A. K. Nayak ${ }^{3}$ and S. Rout ${ }^{4 *}$ \\ ${ }^{1}$ College of Forestry, Orissa University of Agriculture and Technology, Bhubaneswar-751003 (Odisha), INDIA \\ ${ }^{2}$ AICRP on Agroforestry, College of Forestry, Orissa University of Agriculture and Technology, Bhubaneswar-751003 \\ (Odisha), INDIA \\ ${ }^{3}$ Division of Crop production, Central Rice Research Institute, Cuttack-753006 (Odisha), INDIA \\ ${ }^{4}$ School of Forestry \& Environment, Sam Higginbottom Institute of Agriculture Technology \& Sciences, Allahabad \\ -211007 (Uttar Pradesh), INDIA \\ *Corresponding author. E-mail: srout.forestry@gmail.com
}

Received: September 18, 2015; Revised received: February 13, 2016; Accepted: May 16, 2016

\begin{abstract}
The present study was carried out mainly concentrate on assessment of heavy metal in the surrounding soils and their bioconcentration in the different plants near Kathajodi River. Soil and plant samples were collected along the Kathajodi river, Odisha, India. It was found that the dominance of heavy metals follows a decreasing order. The metal concentrations measured in soil at all location generally decreased in the order; $\mathrm{Fe}>\mathrm{Mn}>\mathrm{Ni}>\mathrm{Pb}>\mathrm{Cu}>\mathrm{Zn}>\mathrm{Cd}$. Highest heavy metal concentration in river bank soil $\mathrm{Cd}(0.72 \pm 0.05 \mathrm{mgkg}$ $\left.{ }^{1}\right) ; \mathrm{Ni}\left(3.85 \pm 0.15 \mathrm{mgkg}^{-1}\right) ; \mathrm{Cu}\left(1.66 \pm 0.15 \mathrm{mgkg}^{-1}\right) ; \mathrm{Zn}\left(1.54 \pm 0.16 \mathrm{mgkg}^{-1}\right) ; \mathrm{Pb}\left(4.11 \pm 0.14 \mathrm{mgkg}^{-1}\right) ; \mathrm{Fe}\left(142.0 \pm 1.16 \mathrm{mgkg}^{-1}\right)$; Mn $\left(37.30 \pm 1.16 \mathrm{mgkg}^{-1}\right)$ at different site. Among all the grass species $\mathrm{I}$. laxum has the higher affinity for the accumulation of $\mathrm{Cd}(0.85 \pm 0.05)$ followed by $\mathrm{Zn}, \mathrm{Pb}$ and $\mathrm{Cu}$. This study indicates that bio concentration of heavy metals in the study area show preferential $\mathrm{Cd}$ uptake in the plants followed by $\mathrm{Zn}, \mathrm{Pb}$ and it may lead to accumulates in the exposed plant part posing risk along the food chain. This calls for immediate action to be implemented to carry out necessary environment mitigation measures for the river as it can be attributed the discharge of untreated domestic waste and effluents in the river.
\end{abstract}

Keywords: Bioconcentration, Heavy metals, I. laxum, Kathajodi river, Soil

\section{INTRODUCTION}

Environment is a complex natural resource system that has originated from millenniums of evolutionary process during which all ecosystems and forms of life have developed. Twentieth century particularly has witnessed man's dominance over environment. In recent years, rapid economic and industrial growth intensified environmental pollution. One of the consequences of the escalating industrial activity is the growing accumulation of recalcitrant elements in natural ecosystems; particularly the accumulation of heavy metals in aquatic ecosystem. It has become a problem of great concern throughout the world as these metals are indestructible and have toxic effect on living organisms when they exceeds critical concentration limit (Macfarlane and Burchet, 2000). Increase in population, urbanization, industrialisation and agricultural practices have further aggravated the situation (Giguere et al., 2004).

Heavy metals are of particular concern due to their environmental persistence, biogeochemical recycling and ecological risk. Chemical leaching of bed rocks, water drainage basins and runoff from banks are the primary lithogenic source of heavy metals. Urban discharges and industrial waste water, combustion of fossil fuels, mining and smelting operations, processing and manufacturing industries, waste disposal including dumping etc, are the primary anthropogenic sources of metal pollution (Klavins et. al., 2000; Pardo et. al., 1990; Yu et. al., 2001; Upadhayay et .al., 2006; Barik, 2013). Heavy metals discharged into the aquatic bodies persist for long time and accumulate along the food chain. Metals present in the environment in minute quantities become part of various food chains through biomagnifications and their concentration increases to such a level that may prove to be toxic to both humans and other living organisms (Gopal et. al., 2002).

Study of surrounding soils plays an important role as they have a long residence time. Therefore, are important sources for the assessment of man-made contamination in rivers. Singh et. al., (2002) also reported that highly polluted are adversely affecting the ecological functioning of rivers due to heavy metal mobilization from urban areas in to biosphere. Pollution of the biosphere with toxic heavy metal has accelerated dramatically since the beginning of the industrial revolution. The use of plants has been a common practice for bio monitoring 


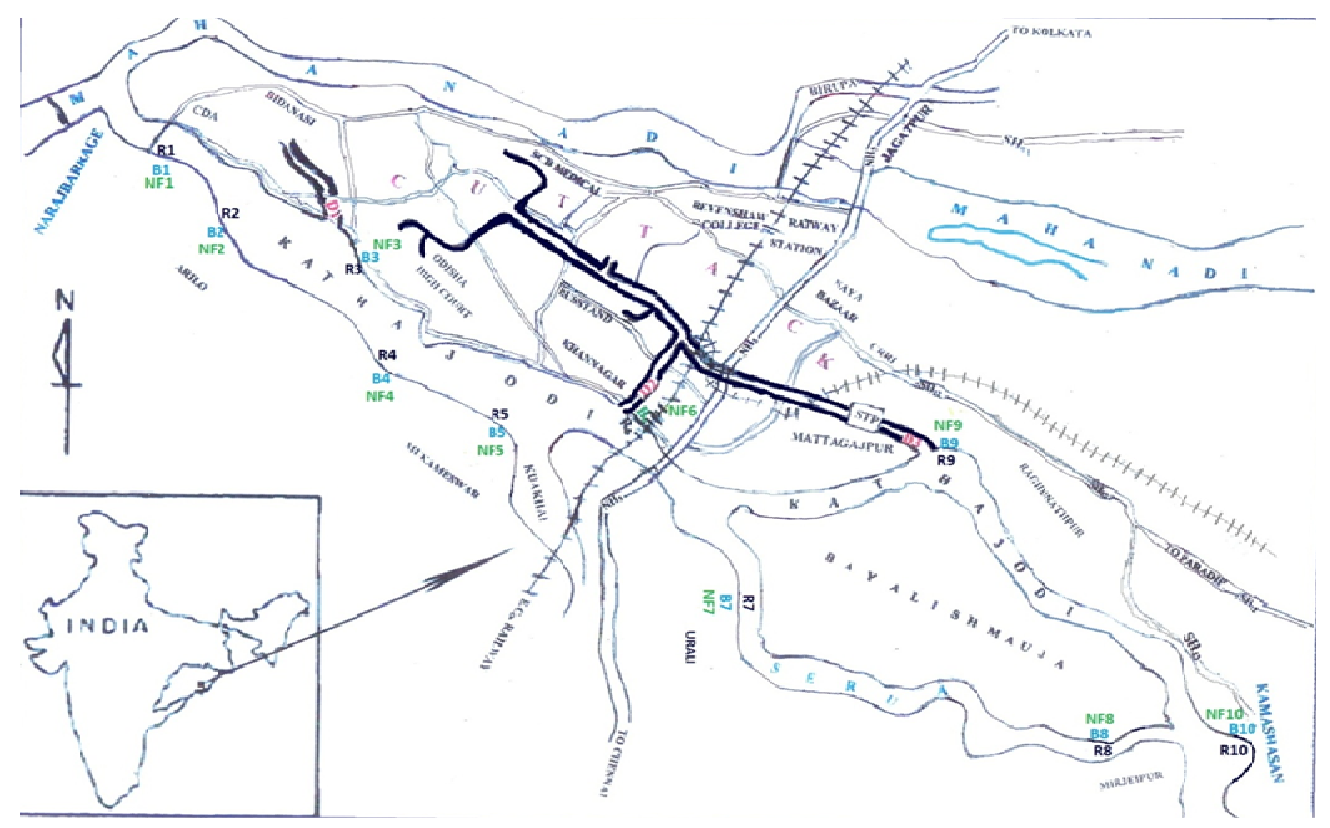

Fig.1. Location of the study area.

of metal contamination and its toxicity.

Cuttack, which is one of the oldest cities of India and was the capital city of Odisha for almost nine centuries was built as a military cantonment in 989 A.D. River Kathajodi in the Cuttack urban area is a significant distributaries of river Mahanadi. The exponential growth of Cuttack on the left side of Kathajodi river has led to severe water pollution in Kathojodi river. The quality of soil in the river bank is seriously affected by pollutants which enter the river through the disposal of untreated domestic and industrial effluents and sewage directly in to the river. During rainy season, when there is a flood in the upper catchment of the river, due to excess discharge of water from the Naraj Barrage, the Kathajodi river swells which enters the adjoining area of the southern bank of Kathajodi river and pollute the soil on the bank as well as the flood pan on the S-E side of the river through sediment deposits. Water coming from upper stream of river Mahanadi also carries sediments containing heavy metals due to its geogenic as well as anthropogenic origin and may contaminates the surrounding soils (De and Mitra, 2002).In order to accesses the heavy metal contamination status of Kathajodi river bank soil the present investigation was carried out to get more information on heavy metals pollution status in the river bank soil and its bioconcentration in plants.

\section{MATERIALS AND METHODS}

Study area: The city Cuttack lies on the east coast of India in the state of Odisha between Latitude: $20^{\circ} 30^{\prime} \mathrm{N}$ and Longitude: $85^{\circ} 49^{\prime} 60^{\prime \prime} \mathrm{E}$. The river Mahanadi and Kathajodi surrounded the city forming a delta on which the city Cuttack is situated Figure.1. The basin displays dendritic to sub dendritic and rarely rectangular and trellises drainage patterns. At the downstream of
Khannagar near Urali village, the river Kathajodi bifurcate and after few kilometre again joined, creating an island namely Bayalishmauja. The right side flow of the Kathajodi is called as Serua river in some area. After the joining of two flows, the river is named as river Devi .The width of Kathajodi river varies from a few hundred meters to two kilometers and is elongated to west to east direction. The river flows in Cuttack district and a few hundred meters in Jagatsinghpur district. The Kathajodi river receives discharge from river Mahanadi. The land surface slopes to the centro-axial zone both from the south and north and also has a low regional gradient to east. As the city is deltaic, being situated between the two rivers, low-lying areas are abundant and are frequently flooded by rain and flood water. The depth of the water table changes with the season, as during pre-monsoon it is 4 to $6 \mathrm{~m}$ below ground level and 0 to $2 \mathrm{~m}$ during post-monsoon (CGWB-1995). The Cuttack city is situated on the N-E side of this river Kathajodi, which receives the sewage and untreated domestic waste which are the causes of pollution.

The city of Cuttack enjoys a subtropical, monsoon climate with three distinct seasons, i.e. summer, winter and rainy. The winter season continues from November to February, the summer extends from March to June, and the rainy season from June to October. The average annual rainfall is $154 \mathrm{~cm}$ with 74 rainy days. The area receives about $85 \%$ of the annual rainfall from south-west monsoons and maximum precipitation occurs in July and August. Cyclonic weather has been a common phenomenon in the study area as it is situated on the east coast of India. The summer is hot and day time temperature reaches $45^{\circ}$ $\mathrm{C}$ with a monthly mean of $39.2^{\circ} \mathrm{C}$. Winter nights reach $8^{\circ}$ $\mathrm{C}$ with a monthly mean temperature of $22.0^{\circ} \mathrm{C}$. The estimated monthly mean combine evaporation and evapotranspiration of the study area is $17.7 \mathrm{~cm}$ (Das et 
Table 1. Description of the study area.

\begin{tabular}{|c|c|c|c|c|}
\hline \multirow[t]{2}{*}{ S. N. } & \multirow[b]{2}{*}{ Sampling station } & \multirow[b]{2}{*}{ Sampling station Description } & \multicolumn{2}{|c|}{ Symbols for the sampling location } \\
\hline & & & $\begin{array}{c}\text { River bank } \\
\text { soil }\end{array}$ & $\begin{array}{l}\text { Nonflooded } \\
\text { soil }\end{array}$ \\
\hline 1 & $\begin{array}{l}\text { Naraj }\left(85^{\circ} 46^{\prime} 47^{\prime \prime} \mathrm{E}\right. \\
\left.20^{\circ} 20^{\prime} 13^{\prime \prime} \mathrm{N}\right)\end{array}$ & $\begin{array}{l}\text { Just after the barrage constructed on } \\
\text { river Kathajodi }\end{array}$ & $\mathrm{B} 1$ & NF1 \\
\hline 2 & $\begin{array}{l}\text { Arilo }\left(85^{\circ} 47^{\prime} 8.5^{\prime \prime} \mathrm{E}\right. \\
\left.20^{\circ} 28^{\prime} 14.9^{\prime \prime} \mathrm{N}\right)\end{array}$ & A bushy wasteland & B2 & NF2 \\
\hline 3 & $\begin{array}{l}\text { CDA-Bidanasi ( } 8548^{\prime} 33^{\prime \prime} \mathrm{E} \\
\left.20^{\circ} 28^{\prime} 3.4^{\prime \prime} \mathrm{N}\right)\end{array}$ & City sewage disposal point & B3 & NF3 \\
\hline 4 & $\begin{array}{l}\text { Bidyadharpur ( } 85^{\circ} 49^{\prime} 26.4^{\prime \prime} \mathrm{E} \\
\left.20^{\circ} 7^{\prime} 14.7^{\prime} \mathrm{N}\right)\end{array}$ & $\begin{array}{l}\text { A farming village with fly ash brick } \\
\text { factory }\end{array}$ & B4 & NF4 \\
\hline 5 & $\begin{array}{l}\text { Brahmanigaon }\left(85^{\circ} 52^{\prime} 7.3^{\prime \prime} \mathrm{E}\right. \\
\left.20^{\circ} 26^{\prime} 56.3^{\prime \prime} \mathrm{N}\right)\end{array}$ & A fishing village & B5 & NF5 \\
\hline 6 & $\begin{array}{l}\text { Khannagar } \\
\left(85^{\circ} 54^{\prime} 3.5^{\prime \prime} \mathrm{E}\right. \\
\left.20^{\circ} 44^{\prime} 30^{\prime \prime} \mathrm{N}\right)\end{array}$ & $\begin{array}{l}\text { Under a bridge of railway track \& } \\
\text { Highway and after the raw city sewage } \\
\text { disposal point }\end{array}$ & B6 & NF6 \\
\hline 7 & $\begin{array}{l}\text { Urali }\left(85^{\circ} 54^{\prime} 14^{\prime \prime} \mathrm{E}\right. \\
\left.20^{\circ} 42^{\prime} 29^{\prime} \mathrm{N}\right)\end{array}$ & $\begin{array}{l}\text { A farming village after the river bifur- } \\
\text { cated opposite side it receives city sew- } \\
\text { age }\end{array}$ & B7 & NF7 \\
\hline 8 & $\begin{array}{l}\text { Mirjeipur } \\
\left(85^{\circ} 58^{\prime} 12^{\prime \prime} \mathrm{E}\right. \\
\left.20^{\circ} 36^{\prime} 46^{\prime \prime} \mathrm{N}\right)\end{array}$ & $\begin{array}{l}\text { A farming village just before the bifur- } \\
\text { cated portion joined to its main river }\end{array}$ & B8 & NF8 \\
\hline 9 & $\begin{array}{l}\text { Raghunathpur } \\
\left(85^{\circ} 59^{\prime} 36^{\prime \prime} \mathrm{E}\right. \\
\left.20^{\circ} 43^{\prime} 38^{\prime \prime} \mathrm{N}\right)\end{array}$ & $\begin{array}{l}\text { A farming village with farming on river } \\
\text { sand and also the sewage disposal in to } \\
\text { river after treatment in a STP. }\end{array}$ & B9 & NF9 \\
\hline 10 & $\begin{array}{l}\text { Komashasan }\left(86^{\circ} 02^{\prime} 43^{\prime \prime} \mathrm{E}\right. \\
\left.20^{\circ} 36^{\prime} 35^{\prime \prime} \mathrm{N}\right)\end{array}$ & A village just after join of the river & B10 & NF10 \\
\hline
\end{tabular}

al., 2002).

Sampling: Ten different sampling stations were selected between Naraj barrage to Koma Shasana village of Jagatsinghpur district and were localized exactly by GPSMAP-6CSX (GRAMIN) locator (Fig.1 and Table 1). Soil samples from $0-15 \mathrm{~cm}$ soil depth from river bank (B1, B2, B3, B4, B5, B6, B7, B8, B9, B10) and non-flooded area control (NF1, NF2, NF3, NF4, NF5, NF6, NF7, NF8, NF9, NF10) were collected during post monsoon period in the month of NovemberDecember 2011. Soil samples were air-dried in the laboratory. Stones and plant fragments were removed from the river bed sediments by passing the dried samples through a $2 \mathrm{~mm}$ sieve. The dried soil samples were grounded and sieved by using $2 \mathrm{~mm}$ sieve. All the samples were then stored in a polythene container and kept ready for analysis (Singh et. al., 2002) and laboratory analysis of soil samples followed during January and February, 2012.

Plants samples: Plants sample are collected for the study are predominant grass and fodder species, samples $(\mathrm{n}=5) C$. dactylon (Dub grass), $P$. repens (Regeda), D. sanguinalis (Kankadaghasa/Digitaria), $S$. diander and I. laxum (Panda suali), of the river bank and non flooded area were uprooted from the adjoining locations from where soil samples were collected, they were washed with 2 per cent detergent water to remove all adhered soil particles. Samples were cut into small pieces, air-dried for 2 days and finally dried at $80^{\circ} \mathrm{C}$ in the hot air oven till a constant weight is achieved and The dried plant sample were ground to fine powder with mortar and pestle. The crusted plant samples were passed through 100 mesh sieves and were preserved for analysis (Burton and Jhan, 1977; Barik, 2013).

Physico-chemical analysis of soil

Determination of $\mathbf{p H}$ and EC: $\mathrm{pH}$ of the soil is determined by a pH meter and EC (Electrical Conductivity) by conductivity bridge (APHA, 2011).

Determination of organic carbon content: Organic carbon was determined by Walkley and Black titration method (Black, 1965).

Determination of available N, P, K: Available $\mathrm{N}$ of the soil was determined by alkaline $\mathrm{KMnO}_{4}$ method (Subbiah and Asija, 1956). Available P was estimated using Olsen's extractant (Jackson, 1973) and available $\mathrm{K}$ was determined using ammonium acetate extractant (Jackson, 1973).

Determination of available heavy metals in soil: Available $\mathrm{Fe}, \mathrm{Cu}, \mathrm{Zn} \mathrm{Mn}, \mathrm{Cd}, \mathrm{Pb}$ and $\mathrm{Ni}$ were determined by atomic absorption spectrophotometer (AAS), using diethylene triamien penta acetic acid (DTPA) as single extractant (Lindsay and Norvell, 1978). The instrument was set to zero by running the respective reagent blanks. Average values of three replicates were taken for each determination.

Determination of heavy metals in plants: Plant samples were weighed exactly $0.5 \mathrm{~g}$ and kept in $5 \mathrm{ml}$ of Nitric Acid $\left(\mathrm{HNO}_{3}\right)$ overnight and followed by its digestion on heating mantle after addition of $5 \mathrm{ml}$ of diacid $\left(\mathrm{HClO}_{4}+\mathrm{HCl}\right)$ mixture on a hot plate under the hood till a clear solution is obtained. Digested sample solution was made to $50 \mathrm{ml}$ volume with the double distilled water. Heavy metal analyses were carried out using flame atomic absorption spectrophotometer 
(Spectra AA, Variant 55B AAS).The calibration curves were prepared separately for all the metals by running different concentrations of standard solutions (AOAC, 2000). The instrument was set to zero by running the respective reagent blanks.

Determination of bioconcentration factor (BCF): Bio Concentration Factor (BCF) is a common parameter for estimating the heavy metal concentration in plants and subsequently enters in to food chain, which is defined as the ratio between the concentration of heavy metals in the plant/flora and DTPA extractable heavy metal concentration in soil (Ghose and Singh, 2005).Data were analyzed for mean and standard deviation. The differences between DTPA-extractable metal contents in soils were statistically evaluated by applying t-test according to Snedecor and Cochran, (1967). Simple correlation and multiple regression analysis were also carried out to assess the relationships of DTPA-extractable metal with plant metal concentration, soil $\mathrm{pH}$ and organic carbon. The relations were tested at $5 \%$ level of significance.

\section{RESULTS AND DISCUSSION}

Physico-chemical characteristic of soil: The values of $\mathrm{pH}, \mathrm{EC}, \mathrm{O} . \mathrm{C}$. and available $\mathrm{N}, \mathrm{P}, \mathrm{K}$ in the soil both river bank are presented in table 2 and 3 . The $\mathrm{pH}$ of river bank soil in all sites was acidic. The highest $\mathrm{pH}$ value was at location $B 8$ with value of $6.9 \pm 0.11$ and lowest at B4 with value of $5.4 \pm 0.14$. In non-flooded area the highest $\mathrm{pH}$ value at NF6 was 6.8 and lowest at NF3was 4.8. The organic carbon per cent was highest at B3 $(0.85 \pm 0.05)$ and lowest at B10 $(0.25 \pm 0.05)$ on the river bank where as in non-flooded area highest organic carbon was observed at NF10 $(0.25 \pm 0.05)$ and lowest at NF3 $(0.12 \pm 0.0)$. The available nitrogen content of $213.4 \pm 1.14 \mathrm{kgha}^{-1}$ was found highest at location B4, lowest at B8 $\left(100.3 \pm 1.15 \mathrm{kgha}^{-1}\right)$ on the river bank whereas on non-flooded soil highest available $\mathrm{N}\left(188.6 \pm 1.15 \mathrm{kgha}^{-1}\right)$ at NF2 and lowest at NF $7\left(87.8 \pm 1.12 \mathrm{kgha}^{-1}\right)$ were observed. Similarly the available $\mathrm{P}$ content was found highest at location $\mathrm{B}_{3}$ $\left(51.7 \pm 1.13 \mathrm{kgha}^{-1}\right)$, lowest at B5 $\left(23.3 \pm 1.13 \mathrm{kgha}^{-1}\right)$ on the river bank whereas on non-flooded soil highest available P $\left(59.5 \pm 1.15 \mathrm{kgha}^{-1}\right)$ at NF4 and lowest at NF $10\left(87.8 \pm 1.12 \mathrm{kgha}^{-1}\right)$ was observed. The available $\mathrm{K}$ content was found highest at location B9 $\left(278.2 \pm 1.12 \mathrm{kgha}^{-1}\right)$ lowest at B5 $\left(100.6 \pm 1.14 \mathrm{kgha}^{-1}\right)$ on the river bank whereas on non-flooded soil highest available K $\left(567.6 \pm 1.14 \mathrm{kgha}^{-1}\right)$ at NF5 and lowest at NF1 $\left(155.6 \pm 1.14 \mathrm{kgha}^{-1}\right)$ was recorded. The presence of higher nutrient level and organic carbon on the river bank site as compared to the non-flooded control site indicted that the former soil is more fertile (Fernandes, 1997). The flood water may carries lot of silts rich in nutrient and organic carbon and deposits on the river bank making it fertile soil. The presence of these parameters showed degree of mineralization due to high rate of loading and inclusion of organic pollutants (Prasad and Kumar, 2008).
DTPA-extractable heavy metal concentration in soil: The heavy metal concentration in soil of river bank and non-flooded area (control) was determined using standard procedures as in material methods. The values are presented in Table 4 and 5, there was wide variation in terms of heavy metal contents with reference to the sampling locations. The average DTPAextractable $\mathrm{Fe}, \mathrm{Cu}, \mathrm{Mn}$ and $\mathrm{Zn}$ varied from $85.5 \pm 1.12$ to $142.0 \pm 1.16 \mathrm{mgkg}^{-1}, 0.46 \pm 0.04$ to $1.64 \pm 0.15 \mathrm{mgkg}^{-1}$, $13.90 \pm 1.12$ to $37.30 \pm 1.16 \mathrm{mgkg}^{-1}$ and $0.67 \pm 0.03$ to $1.54 \pm 0.16 \mathrm{mgkg}^{-1}$, respectively in the river bank soil. Whereas, in non-flooded soil it was varied from $12.2 \pm 1.14$ to $102.5 \pm 1.16 \mathrm{mgkg}^{-1}, \quad 0.44 \pm 0.06$ to $1.42 \pm 0.06 \mathrm{mgkg}^{-1}, 8.05 \pm 1.13$ to $18.95 \pm 1.15 \mathrm{mgkg}^{-1}$, and $0.41 \pm 0.09$ to $1.13 \pm 0.07 \mathrm{mgkg}^{-1}$, respectively. The critical limits of deficiency of $\mathrm{Fe}, \mathrm{Cu}, \mathrm{Mn}$ and $\mathrm{Zn}$ are $4.5 \mathrm{mgkg}^{-1}, 0.2$ to $0.5 \mathrm{mgkg}^{-1}, 2.0 \mathrm{mgkg}^{-1}$ and 0.6 $\mathrm{mgkg}^{-1}$, respectively. This may be due to the disposal of untreated domestic waste and sewage from the city. These are the major source of pollution in river (Mohan et al., 1996). Human and Industrial activities taking place along the river course be the reason for high contamination of all metals the sampling site. The critical limits of deficiency of $\mathrm{Fe}, \mathrm{Cu}, \mathrm{Mn}$ and $\mathrm{Zn}$ are $4.5 \mathrm{mgkg}^{-1}, 0.2$ to $0.5 \mathrm{mgkg}^{-1}, 2.0 \mathrm{mgkg}^{-1}$ and $0.6 \mathrm{mgkg}^{-}$ ${ }^{1}$.The critical limit in soil for contamination as per permissible limit of Indian standard (Gupta et al., 2013) for $\mathrm{Zn}, \mathrm{Cd}, \mathrm{Cu}, \mathrm{Pb}$ and $\mathrm{Ni}$ are $300-600 \mathrm{mgkg}^{-1}, 3-6$ $\mathrm{mgkg}^{-1}, 135-270 \mathrm{mgkg}^{-1}, 250-500 \mathrm{mgkg}^{-1}$ and $75-150$ $\mathrm{mgkg}^{-1}$. All these elements present in the soil of the study area are within the safe limit. The plant micronutrients such as $\mathrm{Fe}, \mathrm{Cu}, \mathrm{Mn}$ and $\mathrm{Zn}$ were present above the critical limit of deficiency indicating its higher fertility status with respect to these elements (Tables.4 and 5).

Cadmium: Highest Cd content was found at B10 and lowest was found at B3 among the river bank soil samples. Among non-flooded soil, highest $\mathrm{Cd}$ content was found at NF4 and lowest was found at NF5. Cd is a non essential elements that can causes kidney damage in human and negatively affect plant growth and development. This was above the probable effect level (Pascual-Barrera et. al., 2004).

Nickel: Highest Ni content was found at B9 and lowest was found at B7 among the river bank soil, whereas highest $\mathrm{Ni}$ content was found at NF 10 and lowest was found at NF6 among non-flooded soil. Small amount Ni may be beneficial to plants and its plant toxicity varies in magnitude according to plant species. Ni poisoning in plants include dwarfing or repression of growth (Sharma, 2001).

Copper: Highest $\mathrm{Cu}$ content was found at B2 and lowest was found at B7 among the river bank soil, whereas highest $\mathrm{Cu}$ content was found at NF 10 and lowest was found at NF4 among non-flooded soil. The copper reaches the aquatic environment through dry and wet deposition which contaminate sediments and soil (Abound and Nandini, 2009). 
Table 2. Some of the chemical parameter of the Kathajodi river bank soil.

\begin{tabular}{|c|c|c|c|c|c|c|c|}
\hline \multirow{2}{*}{ S. N. } & \multirow{2}{*}{ Location } & \multirow{2}{*}{ pH (1:2) } & \multirow{2}{*}{$\operatorname{EC}\left(\mathrm{dSm}^{-1}\right)$} & \multirow{2}{*}{ O.C. $(\%)$} & \multicolumn{3}{|c|}{ Available N, P, K kgha ${ }^{-1}$} \\
\hline & & & & & $\mathbf{N}$ & $\mathbf{P}$ & $\mathbf{K}$ \\
\hline 1 & B1 & $6.5 \pm 0.15$ & $0.57 \pm 0.03$ & $0.28 \pm 0.06$ & $110.2 \pm 1.12$ & $35.6 \pm 1.14$ & $177.9 \pm 1.11$ \\
\hline 2 & $\mathrm{~B} 2$ & $6.4 \pm 0.11$ & $0.26 \pm 0.04$ & $0.32 \pm 0.02$ & $100.5 \pm 1.15$ & $39.5 \pm 1.15$ & $222.3 \pm 1.13$ \\
\hline 3 & B3 & $5.6 \pm 0.13$ & $0.55 \pm 0.05$ & $0.85 \pm 0.05$ & $175.6 \pm 1.14$ & $51.7 \pm 1.13$ & $200.1 \pm 1.11$ \\
\hline 4 & B4 & $5.4 \pm 0.14$ & $0.46 \pm 0.04$ & $0.57 \pm 0.03$ & $213.4 \pm 1.14$ & $26.2 \pm 1.12$ & $255.7 \pm 1.13$ \\
\hline 5 & B5 & $6.7 \pm 0.12$ & $0.29 \pm 0.01$ & $0.48 \pm 0.04$ & $150.7 \pm 1.13$ & $23.3 \pm 1.13$ & $100.6 \pm 1.14$ \\
\hline 6 & B6 & $6.7 \pm 0.13$ & $0.35 \pm 0.05$ & $0.75 \pm 0.05$ & $125.4 \pm 1.14$ & $33.4 \pm 1.14$ & $200.1 \pm 1.11$ \\
\hline 7 & B7 & $5.7 \pm 0.12$ & $0.34 \pm 0.04$ & $0.33 \pm 0.01$ & $112.9 \pm 1.11$ & $28.9 \pm 1.11$ & $234.2 \pm 1.12$ \\
\hline 8 & $\mathrm{~B} 8$ & $6.9 \pm 0.11$ & $0.38 \pm 0.02$ & $0.67 \pm 0.03$ & $100.3 \pm 1.13$ & $29.4 \pm 1.16$ & $256.0 \pm 1.15$ \\
\hline 9 & B9 & $6.1 \pm 0.16$ & $0.55 \pm 0.05$ & $0.47 \pm 0.02$ & $137.8 \pm 1.12$ & $25.6 \pm 1.14$ & $278.2 \pm 1.12$ \\
\hline 10 & B10 & $6.8 \pm 0.13$ & $0.49 \pm 0.01$ & $0.25 \pm 0.05$ & $137.3 \pm 1.13$ & $41.7 \pm 1.13$ & $207.9 \pm 1.11$ \\
\hline
\end{tabular}

Table 3. Chemical parameter of the non-flooded area soil (Control)

\begin{tabular}{|c|c|c|c|c|c|c|c|}
\hline \multirow{2}{*}{$\begin{array}{l}\text { S. } \\
\text { N. }\end{array}$} & \multirow{2}{*}{ Location } & \multirow{2}{*}{ pH (1:2) } & \multirow{2}{*}{$\mathrm{EC}\left(\mathrm{dSm}^{-1}\right)$} & \multirow{2}{*}{ O.C. $(\%)$} & \multicolumn{3}{|c|}{ Available N, P, K kgha ${ }^{-1}$} \\
\hline & & & & & $\mathbf{N}$ & $\mathbf{P}$ & $\mathbf{K}$ \\
\hline 1 & NF1 & $6.4 \pm 0.14$ & $0.57 \pm 0.03$ & $0.24 \pm 0.04$ & $137.9 \pm 1.11$ & $39.5 \pm 1.15$ & $155.6 \pm 1.14$ \\
\hline 2 & NF2 & $6.1 \pm 0.11$ & $0.34 \pm 0.04$ & $0.22 \pm 0.02$ & $188.6 \pm 1.15$ & $42.3 \pm 1.13$ & $522.8 \pm 1.12$ \\
\hline 3 & NF3 & $4.8 \pm 0.12$ & $0.45 \pm 0.05$ & $0.12 \pm 0.01$ & $125.9 \pm 1.11$ & $39.1 \pm 1.11$ & $511.6 \pm 1.14$ \\
\hline 4 & NF4 & $6.1 \pm 0.11$ & $0.38 \pm 0.02$ & $0.15 \pm 0.05$ & $113.6 \pm 1.16$ & $59.5 \pm 1.15$ & $166.8 \pm 1.12$ \\
\hline 5 & NF5 & $6.3 \pm 0.13$ & $0.32 \pm 0.02$ & $0.16 \pm 0.04$ & $163.2 \pm 1.12$ & $38.4 \pm 1.13$ & $567.6 \pm 1.14$ \\
\hline 6 & NF6 & $6.8 \pm 0.12$ & $0.67 \pm 0.03$ & $0.15 \pm 0.05$ & $125.4 \pm 1.14$ & $35.6 \pm 1.14$ & $400.2 \pm 1.12$ \\
\hline 7 & NF7 & $5.7 \pm 0.13$ & $0.38 \pm 0.02$ & $0.13 \pm 0.03$ & $87.8 \pm 1.12$ & $40.4 \pm 1.12$ & $307.8 \pm 1.12$ \\
\hline 8 & NF8 & $6.1 \pm 0.11$ & $0.29 \pm 0.01$ & $0.18 \pm 0.02$ & $137.3 \pm 1.13$ & $32.8 \pm 1.14$ & $292.5 \pm 1.15$ \\
\hline 9 & NF9 & $6.2 \pm 0.12$ & $0.19 \pm 0.01$ & $0.17 \pm 0.03$ & $125.4 \pm 1.12$ & $26.8 \pm 1.12$ & $378.8 \pm 1.12$ \\
\hline 10 & NF10 & $6.0 \pm 0.15$ & $0.26 \pm 0.04$ & $0.25 \pm 0.05$ & $150.1 \pm 1.11$ & $24.7 \pm 1.13$ & $254.7 \pm 1.13$ \\
\hline
\end{tabular}

Table 4. DTPA extractable heavy metal content $\left(\mathrm{mgkg}^{-1}\right)$ in the soils of river bank.

\begin{tabular}{|c|c|c|c|c|c|c|c|c|}
\hline S. N. & Location & Cd & $\mathbf{N i}$ & $\mathrm{Cu}$ & Zn & $\mathbf{P b}$ & $\mathbf{F e}$ & Mn \\
\hline 1 & $\mathrm{~B} 1$ & $0.64 \pm 0.05$ & $2.08 \pm 0.12$ & $0.68 \pm 0.05$ & $0.92 \pm 0.08$ & $1.24 \pm 0.16$ & $85.5 \pm 1.12$ & $16.8 \pm 1.15$ \\
\hline 2 & B2 & $0.47 \pm 0.09$ & $2.24 \pm 0.14$ & $0.46 \pm 0.04$ & $0.85 \pm 0.05$ & $1.12 \pm 0.13$ & $109.5 \pm 1.16$ & $17.2 \pm 1.14$ \\
\hline 3 & B3 & $0.25 \pm 0.03$ & $3.18 \pm 0.12$ & $1.18 \pm 0.12$ & $1.54 \pm 0.16$ & $1.26 \pm 0.14$ & $128.0 \pm 1.14$ & $24.5 \pm 1.16$ \\
\hline 4 & B4 & $0.46 \pm 0.04$ & $3.56 \pm 0.15$ & $1.26 \pm 0.14$ & $0.79 \pm 0.01$ & $3.09 \pm 0.11$ & $120.5 \pm 1.16$ & $25.6 \pm 1.13$ \\
\hline 5 & B5 & $0.68 \pm 0.08$ & $2.98 \pm 0.18$ & $0.58 \pm 0.05$ & $1.12 \pm 0.18$ & $2.26 \pm 0.12$ & $103.5 \pm 1.17$ & $37.3 \pm 1.16$ \\
\hline 6 & B6 & $0.66 \pm 0.06$ & $3.76 \pm 0.11$ & $1.19 \pm 0.13$ & $1.23 \pm 0.17$ & $4.11 \pm 0.14$ & $136.5 \pm 1.13$ & $28.2 \pm 1.14$ \\
\hline 7 & B7 & $0.26 \pm 0.02$ & $3.60 \pm 0.16$ & $1.66 \pm 0.15$ & $0.67 \pm 0.03$ & $2.61 \pm 0.14$ & $129.0 \pm 1.15$ & $23.7 \pm 1.15$ \\
\hline 8 & B8 & $0.72 \pm 0.05$ & $3.45 \pm 0.13$ & $0.85 \pm 0.05$ & $0.75 \pm 0.05$ & $1.35 \pm 0.15$ & $101.8 \pm 1.12$ & $13.9 \pm 1.12$ \\
\hline 9 & B9 & $0.31 \pm 0.01$ & $3.85 \pm 0.15$ & $1.63 \pm 0.17$ & $1.21 \pm 0.09$ & $2.68 \pm 0.12$ & $142.0 \pm 1.16$ & $16.4 \pm 1.17$ \\
\hline 10 & B10 & $0.67 \pm 0.07$ & $2.98 \pm 0.15$ & $0.82 \pm 0.08$ & $0.89 \pm 0.01$ & $1.98 \pm 0.12$ & $122.5 \pm 1.18$ & $17.4 \pm 1.13$ \\
\hline
\end{tabular}

Table 5. DTPA extractable heavy metal content $\left(\mathrm{mgkg}^{-1}\right)$ in the soils of non-flooded area.

\begin{tabular}{|c|c|c|c|c|c|c|c|c|}
\hline S. N. & Location & Cd & $\mathrm{Ni}$ & $\mathbf{C u}$ & $\mathbf{Z n}$ & $\mathbf{P b}$ & $\mathbf{F e}$ & Mn \\
\hline 1 & NF1 & $0.31 \pm 0.02$ & $2.12 \pm 0.02$ & $1.42 \pm 0.06$ & $0.64 \pm 0.06$ & $1.07 \pm 0.08$ & $17.6 \pm 1.12$ & $18.5 \pm 1.15$ \\
\hline 2 & NF2 & $0.46 \pm 0.05$ & $2.06 \pm 0.06$ & $0.66 \pm 0.02$ & $0.44 \pm 0.06$ & $1.19 \pm 0.01$ & $17.3 \pm 1.15$ & $08.2 \pm 1.16$ \\
\hline 3 & NF3 & $0.24 \pm 0.03$ & $3.02 \pm 0.05$ & $0.96 \pm 0.04$ & $1.03 \pm 0.17$ & $1.08 \pm 0.02$ & $102.5 \pm 1.16$ & $08.1 \pm 1.13$ \\
\hline 4 & NF4 & $0.52 \pm 0.07$ & $3.01 \pm 0.07$ & $0.44 \pm 0.06$ & $0.47 \pm 0.03$ & $1.22 \pm 0.03$ & $12.2 \pm 1.14$ & $13.2 \pm 1.12$ \\
\hline 5 & NF5 & $0.14 \pm 0.06$ & $2.07 \pm 0.03$ & $1.15 \pm 0.05$ & $1.13 \pm 0.07$ & $1.28 \pm 0.06$ & $13.6 \pm 1.12$ & $12.3 \pm 1.17$ \\
\hline 6 & NF6 & $0.42 \pm 0.01$ & $1.52 \pm 0.08$ & $1.13 \pm 0.07$ & $0.41 \pm 0.09$ & $1.37 \pm 0.04$ & $59.8 \pm 1.16$ & $15.9 \pm 1.14$ \\
\hline 7 & NF7 & $0.34 \pm 0.08$ & $2.04 \pm 0.05$ & $0.80 \pm 0.05$ & $0.80 \pm 0.05$ & $1.01 \pm 0.01$ & $43.3 \pm 1.17$ & $15.9 \pm 1.16$ \\
\hline 8 & NF8 & $0.51 \pm 0.04$ & $3.02 \pm 0.04$ & $1.32 \pm 0.12$ & $0.76 \pm 0.04$ & $1.34 \pm 0.09$ & $44.9 \pm 1.14$ & $12.5 \pm 1.15$ \\
\hline 9 & NF9 & $0.21 \pm 0.08$ & $2.43 \pm 0.06$ & $1.15 \pm 0.15$ & $0.52 \pm 0.08$ & $1.23 \pm 0.03$ & $65.4 \pm 1.12$ & $15.6 \pm 1.11$ \\
\hline 10 & NF10 & $0.31 \pm 0.05$ & $3.34 \pm 0.01$ & $0.46 \pm 0.14$ & $0.95 \pm 0.05$ & $1.12 \pm 0.05$ & $48.2 \pm 1.15$ & $11.2 \pm 1.12$ \\
\hline
\end{tabular}

Zinc: Highest $\mathrm{Zn}$ content was found at B3 and lowest was found at B7 among the river bank soil, whereas highest $\mathrm{Ni}$ content was found at NF 10 and lowest was found at NF6 among non-flooded soil. This may be due to effluent and urban sewage (Abbasi et.al., 1998). Lead: Highest $\mathrm{Pb}$ content was found at $\mathrm{B} 6$ and lowest was found at B2 among the river bank soil, whereas highest $\mathrm{Pb}$ content was found at NF 6 and lowest was found at NF2 among non-flooded soil. Location B6 and NF6 are close to the highways and influenced by the automobile emission hence the $\mathrm{Pb}$ content is obviously higher in these location and also due to other activity near the river (Abbasi et. al., 1998). Pb toxicity may cause amnesia and accelerating red blood cell destruction in human being (Anglin-Brown et. al., 1995).

Iron: Highest Fe content was found at B9 and lowest was found at B1 among the river bank soil, whereas 


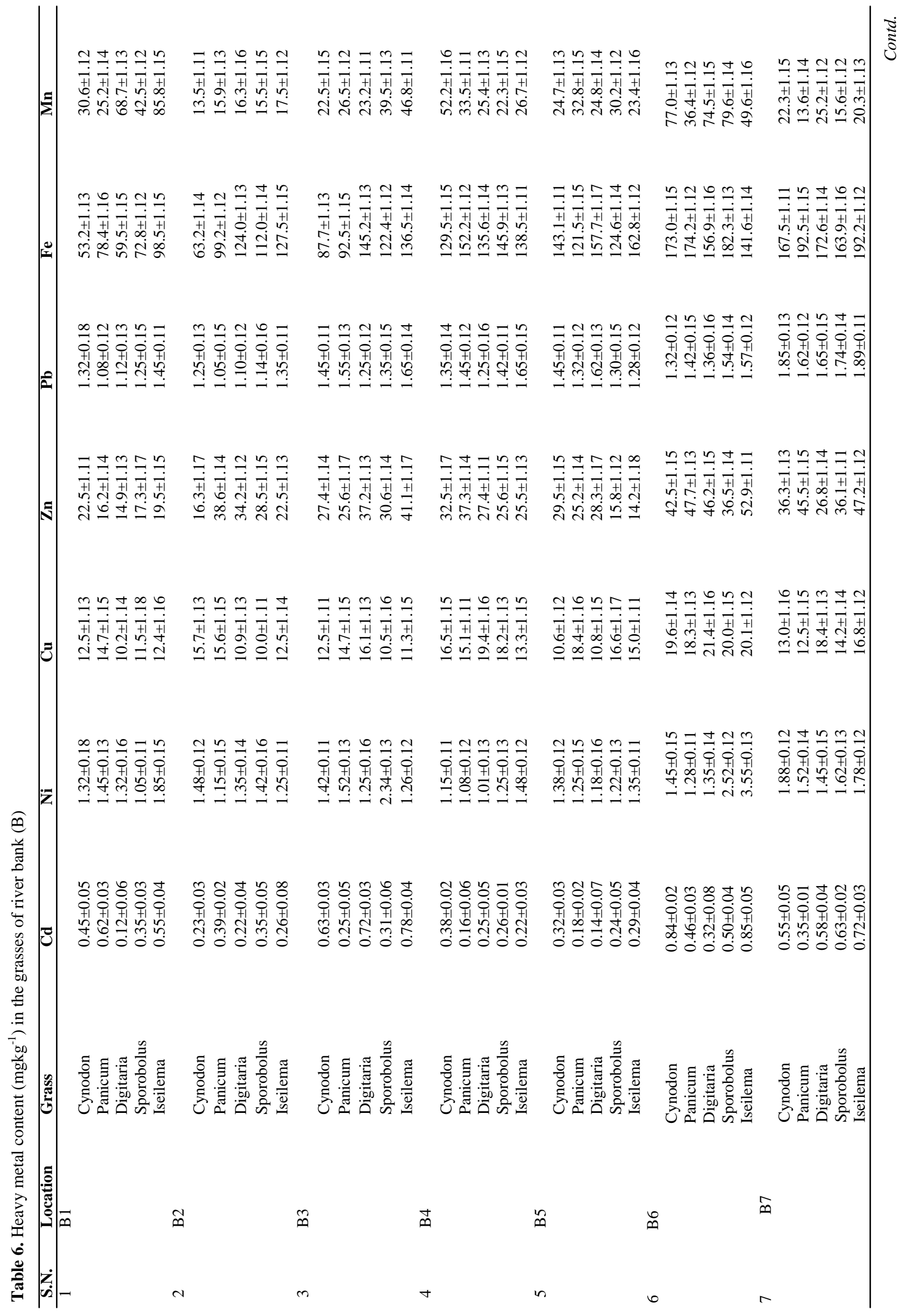




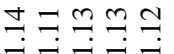

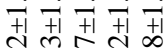 \\ จิㅊํํำ

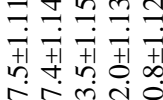 \\ 들ํㅇ}

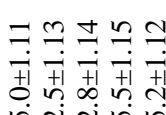

어웜응

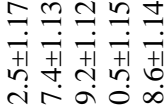

의

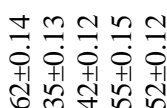
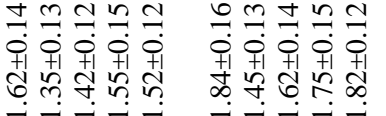

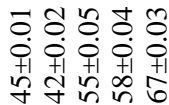

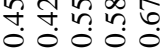

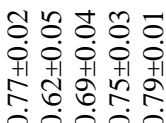

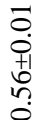

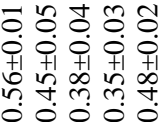

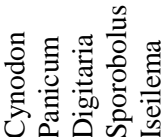

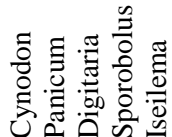

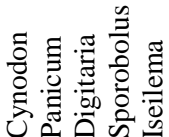

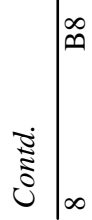

ติ

$\stackrel{\circ}{\infty}$

a highest Fe content was found at NF1 and lowest was found at NF3 among non-flooded soil.

Manganese: Highest Mn content was found at B5 and lowest was found at B8 among the river bank soil, whereas highest Mn content was found at NF1 and lowest was found at NF3 among non-flooded soil. The metal concentrations measured in soil at both the sites i.e. river bank and non flooded generally decreased in the order; $\mathrm{Fe}>\mathrm{Mn}>\mathrm{Ni}>\mathrm{Pb}>\mathrm{Cu}>\mathrm{Zn}>\mathrm{Cd}$. although this pattern varied moderately between $\mathrm{Ni}$ and $\mathrm{Pb}$, there was no statistical difference in DTPA extractable heavy metal content viz. $\mathrm{Cu}, \mathrm{Zn}, \mathrm{Pb}, \mathrm{Ni}$ and $\mathrm{Cd}$ in the soils of river bank and non flooded. However soil of river bank showed higher available Fe and Mn content. The soils on the river bank situated in the low lying area subjected to flooding by the river water and remained water logging for a considerable period of time, under reducing environment the reduced species of $\mathrm{Fe}$ and $\mathrm{Mn}$ are always higher than the soil remained dry and aerated. Additionally flood water might have carried out $\mathrm{Fe}$ and $\mathrm{Mn}$ bearing materials from the upper catchment of Mahanadi and deposited on the river bank. The pattern of variation of $\mathrm{Fe}$ and Mn concentration in the soils of river bank as well as in non flooded soil was similar from Naraj to Komashasana along the river stream. Moreover the Mn concentration was reduced at B8, B9 and B10 located on the river bank towards downstream indicating that sewage effluents may not be a source of Fe and $\mathrm{Mn}$ deposit on the river bank (Barik, 2013).

Heavy metal concentration in plants: Five grasses namely $C$. dactylon (Dub grass), $P$. repens (Regeda), $D$. sanguinalis (Kankadaghasa/Crab grass), S. diander (Jhari grass) and I. laxum (Panda Suali grass) naturally grown on both the river bank soil as in non flooded soil and mostly used for cattle feeding in the locality were collected as representative vegetation samples and the heavy metal content was determined by using standard procedures as laid down in materials and methods. The values are presented in table 6 and 7 . It was found that most of the heavy metal concentration in different grass species grown on the river bank were statistical at par with those grown on non-flooded area. There was wide variation in terms of heavy metal contents with reference to the location of the samples. Lokeshwari and Chandrappa, (2006) has reported more heavy metal accumulation in plants grown in the sewage irrigated soil near the Bellandur lake, Bangalore city, Karnataka are agreement with this. Among the species there was a wide variation in the heavy metal accumulation. P. repens has the highest quantity of $\mathrm{Fe}$ content, $S$. diander has highest quantity of $\mathrm{Cu}$ and I. laxum has highest quantities of $\mathrm{Mn}(85 \pm 1.15) \mathrm{mgkg}^{-1}, \mathrm{Zn}(94.1 \pm 1.14) \mathrm{mgkg}^{-}$ ${ }^{1}, \mathrm{Cd}(0.85 \pm 0.05) \mathrm{mgkg}^{-1}, \mathrm{Ni}(3.55 \pm 0.13) \mathrm{mgkg}^{-1}$ and $\mathrm{Pb}(1.89 \pm 0.11) \mathrm{mgkg}^{-1}$. This indicates I. laxum is a good accumulator of heavy metals as reported by Lokeshwari and Chandrapa (2006). The accumulation of particular metals is compared with the presence of 


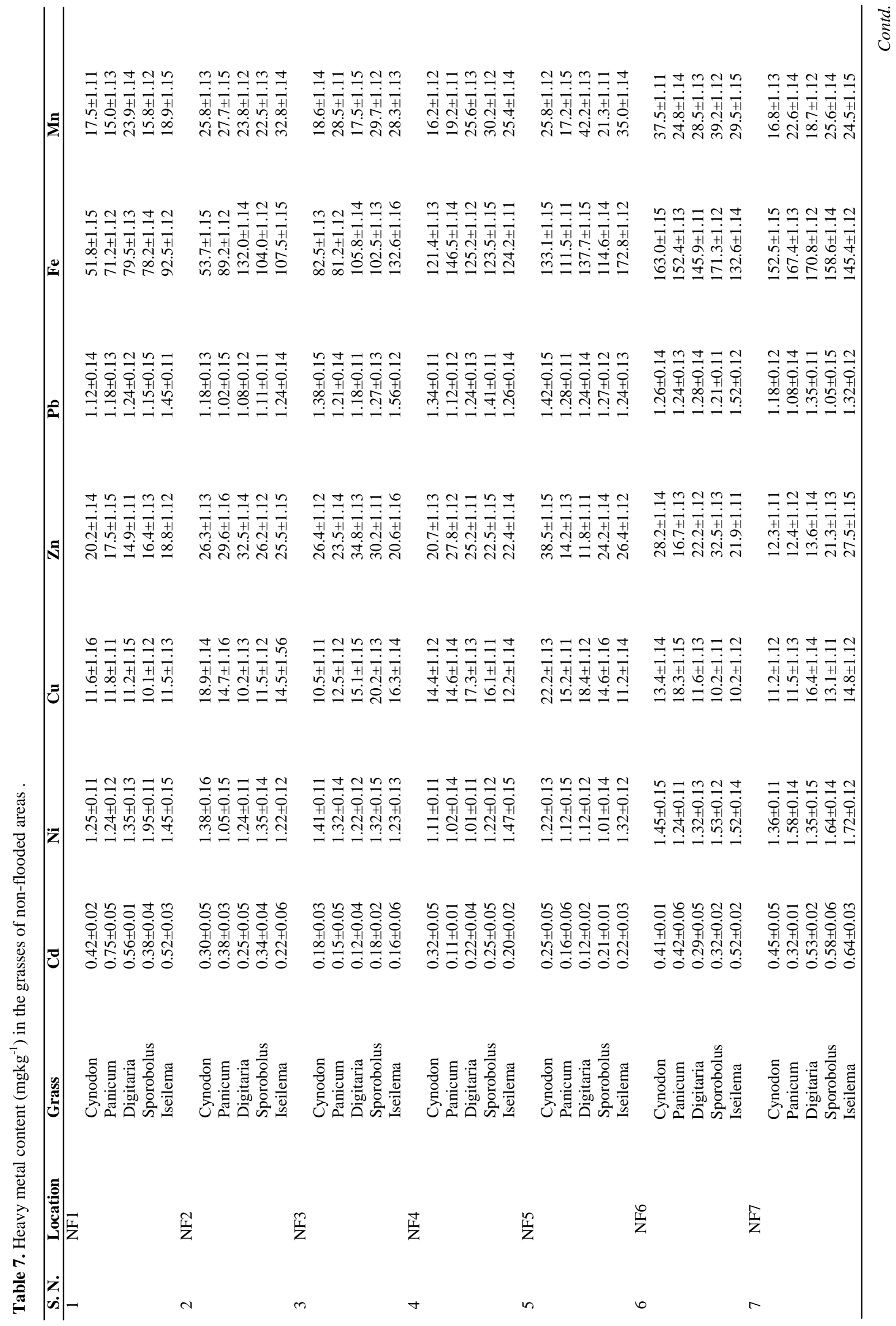


that metal in soil.

Cadmium: The Cd content in $C$. dactylon, $P$. repens, $D$. sanguinalis, $S$. diander and I. laxum in the river bank were varied between 0.23 to $0.84 \mathrm{mgkg}^{-1}$, $0.16 \pm 0.06$ to $0.62 \pm 0.05 \mathrm{mgkg}^{-1}, \quad 0.12 \pm 0.02$ to $0.72 \pm 0.02 \mathrm{mgkg}^{-1}, 0.24 \pm 0.05$ to $0.75 \pm 0.03 \mathrm{mgkg}^{-1}$ and $0.22 \pm 0.03$ to $0.85 \mathrm{mgkg}^{-1}$ respectively. Whereas nonflooded soil, the $\mathrm{Cd}$ content varied between $0.18 \pm 0.02$ to $0.68 \pm 0.05 \mathrm{mgkg}^{-1}, 0.11 \pm 0.01$ to $0.75 \pm 0.05 \mathrm{mgkg}^{-1}$, $0.12 \pm 0.02$ to $0.62 \pm 0.04 \mathrm{mgkg}^{-1}, 0.18 \pm 0.02$ to $0.72 \pm 0.02 \mathrm{mgkg}^{-1}$ and $0.16 \pm 0.06$ to $0.67 \pm 0.02 \mathrm{mgkg}^{-1}$, respectively. Grass species studied, highest concentration of Cd was found in I. laxum at both river bank non -flooded soil. This may be due to in plants $\mathrm{Cd}$ accumulates in several tissue and complexes with amino acids, organic acids and other major parts of plant metabolism (Benavides et. al., 2005).

Nickel: The Ni content in C. dactylon, P. repens, D. sanguinalis, $S$. diander and I. laxum in the river bank are varied between $1.15 \pm 0.11$ to $2.72 \pm 0.13 \mathrm{mgkg}^{-1}$, $1.08 \pm 0.12$ to $1.78 \pm 0.11 \mathrm{mgkg}^{-1}, 1.01 \pm 0.13$ to $1.88 \pm 0.12 \mathrm{mgkg}^{-1}, 1.05 \pm 0.11$ to $2.52 \pm 0.12 \mathrm{mgkg}^{-1}$ and $1.25 \pm 0.11$ to $3.55 \pm 0.13 \mathrm{mgkg}^{-1}$ respectively. Whereas in non-flooded soil, the $\mathrm{Ni}$ content varied between $1.11 \pm 0.11$ to $2.32 \pm 0.14 \mathrm{mgkg}^{-1}, 1.02 \pm 0.14$ to $1.64 \pm 0.14 \mathrm{mgkg}^{-1}, \quad 1.01 \pm 0.11$ to $1.75 \pm 0.15 \mathrm{mgkg}^{-1}$, $1.01 \pm 0.14$ to $1.95 \pm 0.11 \mathrm{mgkg}^{-1}$ and $1.22 \pm 0.12 \mathrm{mgkg}^{-1}$ to $2.18 \pm 0.12 \mathrm{mgkg}^{-1}$, respectively. Grass species studied, highest concentration of $\mathrm{Ni}$ was found in I. laxum at river bank soil and $C$. dactylon in non flooded soil. This may causes plant toxicity by dwarfing or repressing of growth (Sharma, 2001).

Copper: The $\mathrm{Cu}$ content in $C$. dactylon, P. repens, $D$. sanguinalis, $S$. diander and I. laxumin the river bank are varied between $12.5 \pm 1.13$ to $34.4 \pm 1.13 \mathrm{mgkg}^{-1}$, $11.3 \pm 1.13$ to $18.4 \pm 1.16 \mathrm{mgkg}^{-1}, 10.2 \pm 1.14$ to $21.4 \pm 1.16$ $\mathrm{mgkg}^{-1}, 10.0 \pm 1.11$ to $24.4 \pm 1.14 \mathrm{mgkg}^{-1}$ and $11.3 \pm 1.15$ to $20.1 \pm 1.12 \mathrm{mgkg}^{-1}$ respectively. Whereas in non-flooded soil, the $\mathrm{Cu}$ content varied between $10.5 \pm 1.11$ to $28.5 \pm 1.15$ $\mathrm{mgkg}^{-1}, 10.3 \pm 1.13$ to $21.4 \pm 1.13 \mathrm{mgkg}^{-1}, 10.2 \pm 1.13$ to $20.1 \pm 1.11 \mathrm{mgkg}^{-1}, 10.1 \pm 0.12$ to $29.2 \pm 1.12 \mathrm{mgkg}^{-1}$ and $10.2 \pm 1.12 \mathrm{mgkg}^{-1}$ to $18.6 \pm 1.14 \mathrm{mgkg}^{-1}$. The grass species studied, highest concentration of $\mathrm{Cu}$ was found in $C$. dactylon at the river bank and non flooded soil. Similar findings are also reported by Abbassi et al. (1998).

Zinc: The $\mathrm{Zn}$ content in $C$. dactylon, $P$. repens, D. sanguinalis, $S$. diander and I. laxumin the river bank are varied between $16.3 \pm 1.17$ to $42.5 \pm 1.15 \mathrm{mgkg}^{-1}, 16.2 \pm 1.14$ to $47.7 \pm 1.13 \mathrm{mgkg}^{-1}, 14.9 \pm 1.13$ to $46.2 \pm 1.15 \mathrm{mgkg}^{-1}$, $15.8 \pm 1.12$ to $36.5 \pm 1.14 \mathrm{mgkg}^{-1}$ and $14.2 \pm 1.18$ to $52.9 \pm 1.11 \mathrm{mgkg}^{-1}$ respectively. Whereas non-flooded soil, the $\mathrm{Cu}$ content varied between $12.3 \pm 1.11$ to $38.5 \pm 1.15 \mathrm{mgkg}^{-1}, 12.4 \pm 1.12$ to $29.6 \pm 1.16 \mathrm{mgkg}^{-1}$, $11.8 \pm 1.11$ to $35.4 \pm 1.14 \mathrm{mgkg}^{-1}, \mathrm{mgkg}^{-1}, 16.4 \pm 1.13$ to $32.5 \pm 1.13 \mathrm{mgkg}^{-1}$ and $18.8 \pm 1.12$ to $38.5 \pm 1.15 \mathrm{mgkg}^{-1}$, respectively. Grass species studied, highest concentration of $\mathrm{Zn}$ was found in I. laxum at the river bank. 
Table 8 . Correlation matrix among soil properties and metal content in the grass species.

\begin{tabular}{|c|c|c|c|c|c|c|}
\hline Particulars & pH & EC & OC & $\mathbf{N}$ & $\mathbf{P}$ & $\mathbf{K}$ \\
\hline \multicolumn{7}{|l|}{ C. dactylon } \\
\hline $\mathrm{Cd}$ & 0.21 & 0.11 & $0.49^{*}$ & -0.07 & -0.25 & -0.33 \\
\hline $\mathrm{Ni}$ & 0.06 & -0.11 & 0.05 & -0.17 & $-0.49 *$ & 0.03 \\
\hline $\mathrm{Cu}$ & 0.27 & $-0.44 *$ & -0.12 & 0.20 & -0.16 & 0.27 \\
\hline $\mathrm{Zn}$ & 0.11 & -0.13 & 0.30 & 0.39 & $-0.45^{*}$ & 0.17 \\
\hline $\mathrm{Pb}$ & 0.04 & 0.23 & 0.37 & -0.09 & -0.13 & -0.13 \\
\hline $\mathrm{Fe}$ & 0.15 & -0.18 & 0.10 & -0.13 & -0.42 & -0.04 \\
\hline $\mathrm{Mn}$ & 0.20 & 0.01 & $0.48 *$ & 0.24 & -0.30 & -0.04 \\
\hline \multicolumn{7}{|l|}{ P. repens } \\
\hline $\mathrm{Cd}$ & 0.43 & 0.25 & -0.03 & -0.28 & -0.27 & -0.22 \\
\hline $\mathrm{Ni}$ & -0.01 & 0.05 & 0.09 & -0.30 & -0.36 & -0.18 \\
\hline $\mathrm{Cu}$ & 0.37 & -0.23 & 0.20 & 0.03 & -0.21 & 0.07 \\
\hline $\mathrm{Zn}$ & -0.08 & -0.12 & $0.57 *$ & 0.08 & -0.13 & -0.26 \\
\hline $\mathrm{Pb}$ & -0.06 & 0.33 & $0.65 *$ & 0.24 & -0.15 & -0.26 \\
\hline $\mathrm{Fe}$ & 0.08 & -0.20 & 0.19 & -0.27 & -0.32 & -0.10 \\
\hline $\mathrm{Mn}$ & -0.23 & 0.01 & 0.30 & $0.45^{*}$ & -0.15 & 0.00 \\
\hline \multicolumn{7}{|l|}{ D. sanguinalis } \\
\hline $\mathrm{Cd}$ & -0.05 & 0.09 & 0.30 & -0.12 & -0.09 & -0.21 \\
\hline $\mathrm{Ni}$ & 0.22 & -0.08 & 0.02 & -0.36 & $-0.47 *$ & -0.03 \\
\hline $\mathrm{Cu}$ & -0.27 & -0.31 & 0.15 & 0.10 & 0.00 & 0.07 \\
\hline $\mathrm{Zn}$ & -0.14 & -0.13 & $0.56^{*}$ & 0.10 & -0.04 & -0.03 \\
\hline $\mathrm{Pb}$ & 0.15 & 0.08 & 0.34 & -0.17 & -0.36 & -0.31 \\
\hline $\mathrm{Fe}$ & 0.04 & -0.36 & 0.24 & -0.02 & -0.27 & 0.06 \\
\hline $\mathrm{Mn}$ & 0.35 & 0.14 & 0.26 & -0.06 & -0.06 & -0.13 \\
\hline \multicolumn{7}{|l|}{ S. diander } \\
\hline $\mathrm{Cd}$ & 0.13 & -0.19 & 0.10 & -0.40 & -0.41 & -0.10 \\
\hline $\mathrm{Ni}$ & 0.06 & 0.17 & $0.59 *$ & -0.05 & 0.10 & -0.32 \\
\hline $\mathrm{Cu}$ & 0.14 & $-0.60 *$ & 0.20 & 0.14 & -0.40 & -0.18 \\
\hline $\mathrm{Zn}$ & -0.14 & 0.07 & 0.32 & -0.06 & -0.09 & 0.24 \\
\hline $\mathrm{Pb}$ & 0.03 & 0.15 & $0.49 *$ & 0.01 & -0.25 & -0.31 \\
\hline $\mathrm{Fe}$ & 0.14 & -0.15 & 0.29 & -0.17 & -0.37 & 0.00 \\
\hline $\mathrm{Mn}$ & 0.29 & 0.37 & 0.45 & -0.04 & -0.06 & -0.22 \\
\hline \multicolumn{7}{|l|}{ I.laxum } \\
\hline $\mathrm{Cd}$ & 0.22 & 0.17 & 0.44 & -0.31 & -0.22 & -0.32 \\
\hline $\mathrm{Ni}$ & 0.26 & -0.07 & 0.29 & -0.20 & -0.27 & -0.23 \\
\hline $\mathrm{Cu}$ & -0.09 & $-0.50 *$ & 0.06 & -0.13 & -0.30 & -0.02 \\
\hline $\mathrm{Zn}$ & -0.11 & -0.17 & $0.46^{*}$ & -0.04 & -0.08 & -0.03 \\
\hline $\mathrm{Pb}$ & -0.21 & $0.53 *$ & $0.49 *$ & 0.01 & -0.15 & -0.19 \\
\hline $\mathrm{Fe}$ & -0.14 & -0.35 & 0.13 & -0.04 & -0.41 & 0.15 \\
\hline $\mathrm{MN}$ & 0.07 & 0.22 & 0.10 & 0.04 & 0.03 & -0.08 \\
\hline
\end{tabular}

* Significant at $\mathrm{p}<0.05$

Similar findings are also reported by Pascal-Burresa $e t$ al., (2004).

Lead: The $\mathrm{Pb}$ content in $C$. dactylon, $P$. repens, $D$. sanguinalis, $S$. diander and I. laxum at river bank were varied between $1.25 \pm 0.13$ to $1.85 \pm 0.13 \mathrm{mgkg}^{-1}$, $1.05 \pm 0.15$ to $1.62 \pm 0.12 \mathrm{mgkg}^{-1}, 1.14 \pm 0.16 \mathrm{mgkg}^{-1}$, $1.14 \pm 0.16$ to $1.75 \pm 0.15 \mathrm{mgkg}^{-1}$ and $1.28 \pm 0.12$ to $1.89 \pm 0.11 \mathrm{mgkg}^{-1}$ respectively. Grass species studied, highest concentration of $\mathrm{Zn}$ was found in I. laxum at the river bank as well as non-flooded soil. It was in agreement with critical range of $\mathrm{Pb}$ as described by Nirmal et al. (2006).

Iron: The Fe content in C. dactylon, P. repens, D. sanguinalis, S. diander and I. laxum are varied between
$53.2 \pm 1.13 \mathrm{mgkg}^{-1}$ to $173.0 \pm 1.15 \mathrm{mgkg}^{-1}, 78.4 \pm 1.16$ to $192.1 \pm 1.15 \mathrm{mgkg}^{-1}, 59.5 \pm 1.15 \mathrm{mgkg}^{-1}$ to $172.6 \pm 1.14$ $\mathrm{mgkg}^{-1}, \quad 72.8 \pm 1.12$ to $182.3 \pm 1.13 \mathrm{mgkg}^{-1}$ and $98.5 \pm 1.15$ to $192.2 \pm 1.12 \mathrm{mgkg}^{-1}$ respectively. Grass species studied, highest concentration of Fe was found in I. laxum at river bank as well as non-flooded soil. The river bank and non-flooded soil had higher Fe concentration. This may be due to the heavy metal accumulation in the river bank by the flood during rainy season (Bhargava et. al., 2009).

Manganese: The Mn content in C. dactylon, $P$. repens, D. sanguinalis, $S$. diander and I. laxum are varied between $13.5 \pm 1.11$ to $77.0 \pm 1.13 \mathrm{mgkg}^{-1}, 12.3 \pm 1.11$ to $36.4 \pm 1.12 \mathrm{mgkg}^{-1}, 16.3 \pm 1.16$ to $74.5 \pm 1.15 \mathrm{mgkg}^{-1}$, 
Table 9. Bio Concentration Factors ( $\left.\mathrm{mg} / \mathrm{kg}_{\mathrm{dwt} \text {.plant }} / \mathrm{mg} / \mathrm{kg}_{\mathrm{dwt} . \text { soil }}\right)$ of heavy metals of river bank .

\begin{tabular}{|c|c|c|c|c|c|c|c|c|c|}
\hline S. N. & Location & Grass & Cd & $\mathrm{Ni}$ & $\mathrm{Cu}$ & Zn & $\mathbf{P b}$ & $\mathbf{F e}$ & Mn \\
\hline \multirow[t]{6}{*}{1} & B1 & & & & & & & & \\
\hline & & Cynodon & 0.70 & 0.63 & 18.3 & 24.4 & 1.06 & 0.62 & 1.81 \\
\hline & & Panicum & 0.96 & 0.69 & 21.6 & 17.6 & 0.87 & 0.91 & 1.50 \\
\hline & & Digitaria & 0.35 & 0.63 & 15.0 & 16.1 & 0.90 & 0.69 & 4.10 \\
\hline & & Sporobolus & 0.54 & 0.50 & 16.9 & 18.8 & 1.01 & 0.85 & 2.50 \\
\hline & & Iseilema & 0.85 & 0.88 & 18.2 & 21.2 & 1.16 & 1.15 & 5.10 \\
\hline \multirow[t]{6}{*}{2} & B2 & & & & & & & & \\
\hline & & Cynodon & 0.48 & 0.66 & 34.1 & 19.1 & 1.10 & 0.57 & 0.78 \\
\hline & & Panicum & 0.82 & 0.51 & 33.9 & 45.5 & 0.93 & 0.90 & 0.92 \\
\hline & & Digitaria & 0.46 & 0.60 & 23.6 & 40.2 & 0.98 & 1.13 & 0.94 \\
\hline & & Sporobolus & 0.74 & 0.63 & 21.7 & 33.5 & 1.01 & 1.02 & 0.90 \\
\hline & & Iseilema & 0.55 & 0.55 & 27.1 & 26.4 & 1.20 & 1.16 & 1.01 \\
\hline \multirow[t]{6}{*}{3} & B3 & & & & & & & & \\
\hline & & Cynodon & 2.50 & 0.44 & 10.6 & 17.8 & 1.15 & 0.68 & 0.91 \\
\hline & & Panicum & 1.00 & 0.70 & 12.4 & 16.6 & 1.23 & 0.72 & 1.20 \\
\hline & & Digitaria & 0.48 & 0.39 & 13.6 & 24.1 & 0.99 & 1.13 & 0.94 \\
\hline & & Sporobolus & 0.84 & 0.73 & 8.9 & 19.8 & 1.07 & 0.95 & 1.61 \\
\hline & & Iseilema & 0.91 & 0.39 & 9.6 & 26.6 & 1.30 & 1.06 & 1.91 \\
\hline \multirow[t]{6}{*}{4} & B4 & & & & & & & & \\
\hline & & Cynodon & 0.82 & 0.32 & 13.1 & 41.1 & 4.40 & 1.07 & 2.03 \\
\hline & & Panicum & 0.34 & 0.30 & 11.9 & 47.2 & 0.50 & 1.26 & 1.31 \\
\hline & & Digitaria & 0.54 & 0.28 & 15.4 & 34.6 & 0.40 & 1.12 & 0.99 \\
\hline & & Sporobolus & 0.56 & 0.35 & 14.4 & 32.4 & 0.40 & 1.21 & 0.87 \\
\hline & & Iseilema & 0.47 & 0.41 & 10.5 & 32.3 & 0.50 & 1.14 & 1.04 \\
\hline \multirow[t]{6}{*}{5} & B5 & & & & & & & & \\
\hline & & Cynodon & 0.47 & 0.46 & 18.3 & 26.3 & 0.64 & 1.38 & 0.66 \\
\hline & & Panicum & 0.26 & 0.41 & 31.7 & 22.5 & 0.58 & 1.17 & 0.87 \\
\hline & & Digitaria & 0.20 & 0.39 & 18.6 & 25.3 & 0.71 & 1.52 & 0.66 \\
\hline & & Sporobolus & 0.35 & 0.40 & 28.6 & 14.1 & 0.57 & 1.20 & 0.80 \\
\hline & & Iseilema & 0.42 & 0.45 & 25.8 & 12.6 & 0.56 & 1.57 & 0.62 \\
\hline \multirow[t]{6}{*}{6} & B6 & & & & & & & & \\
\hline & & Cynodon & 1.27 & 0.38 & 16.5 & 34.5 & 0.32 & 1.26 & 2.73 \\
\hline & & Panicum & 0.69 & 0.34 & 15.4 & 38.7 & 0.34 & 1.27 & 1.29 \\
\hline & & Digitaria & 0.48 & 0.35 & 18.0 & 37.5 & 0.33 & 1.14 & 2.64 \\
\hline & & Sporobolus & 0.75 & 0.67 & 16.8 & 29.6 & 0.37 & 1.33 & 2.82 \\
\hline & & Iseilema & 1.28 & 0.94 & 25.2 & 43.0 & 0.38 & 1.03 & 1.75 \\
\hline \multirow[t]{6}{*}{7} & B7 & & & & & & & & \\
\hline & & Cynodon & 2.11 & 0.52 & 7.8 & 54.1 & 1.04 & 1.29 & 0.94 \\
\hline & & Panicum & 1.34 & 0.42 & 7.5 & 67.9 & 1.10 & 1.49 & 0.57 \\
\hline & & Digitaria & 2.23 & 0.40 & 11.1 & 40.0 & 1.15 & 1.33 & 1.06 \\
\hline & & Sporobolus & 2.42 & 0.45 & 8.5 & 53.9 & 1.07 & 1.27 & 0.65 \\
\hline & & Iseilema & 2.70 & 0.49 & 10.1 & 70.4 & 1.35 & 1.48 & 0.85 \\
\hline \multirow[t]{6}{*}{8} & B8 & & & & & & & & \\
\hline & & Cynodon & 0.62 & 0.47 & 18.2 & 34.2 & 0.99 & 1.22 & 2.10 \\
\hline & & Panicum & 0.58 & 0.42 & 18.1 & 37.6 & 0.85 & 1.59 & 0.88 \\
\hline & & Digitaria & 0.76 & 0.44 & 15.5 & 35.7 & 0.90 & 1.50 & 1.63 \\
\hline & & Sporobolus & 0.80 & 0.45 & 18.2 & 38.5 & 0.93 & 1.62 & 2.31 \\
\hline & & Iseilema & 1.05 & 0.39 & 14.9 & 38.0 & 1.04 & 1.32 & 1.64 \\
\hline \multirow[t]{6}{*}{9} & B9 & & & & & & & & \\
\hline & & Cynodon & 2.5 & 0.70 & 8.8 & 29.1 & 1.27 & 1.14 & 1.06 \\
\hline & & Panicum & 2.0 & 0.46 & 8.3 & 28.4 & 1.12 & 1.10 & 1.06 \\
\hline & & Digitaria & 2.2 & 0.48 & 7.5 & 29.3 & 1.09 & 1.12 & 1.43 \\
\hline & & Sporobolus & 2.4 & 0.42 & 6.9 & 29.9 & 1.17 & 1.13 & 4.39 \\
\hline & & Iseilema & 2.5 & 0.56 & 7.3 & 28.2 & 1.44 & 1.18 & 2.48 \\
\hline \multirow[t]{6}{*}{10} & B10 & & & & & & & & \\
\hline & & Cynodon & 0.83 & 0.58 & 31.2 & 38.6 & & 1.17 & 1.20 \\
\hline & & Panicum & 0.67 & 0.55 & 13.7 & 21.5 & 0.75 & 0.84 & 0.83 \\
\hline & & Digitaria & 0.56 & 0.48 & 21.0 & 20.8 & 0.68 & 1.20 & 1.37 \\
\hline & & Sporobolus & 0.52 & 0.52 & 17.5 & 29.4 & 0.74 & 1.10 & 3.17 \\
\hline & & Iseilema & 0.71 & 0.62 & 20.1 & 24.3 & 0.76 & 1.03 & 1.67 \\
\hline
\end{tabular}


Table 10. Bio Concentration Factors ( $\left.\mathrm{mg} / \mathrm{kg}_{\mathrm{dwt} . \text { plant }} / \mathrm{mg} / \mathrm{kg}_{\mathrm{dwt} . \text { soil }}\right)$ of heavy metals of non-flooded area

\begin{tabular}{|c|c|c|c|c|c|c|c|c|c|}
\hline S. N. & Location & Grass & Cd & $\mathbf{N i}$ & $\mathbf{C u}$ & $\mathbf{Z n}$ & $\mathbf{P b}$ & $\mathbf{F e}$ & Mn \\
\hline \multirow[t]{6}{*}{1} & NF1 & & & & & & & & \\
\hline & & Cynodon & 1.35 & 0.58 & 8.16 & 31.5 & 1.04 & 2.94 & 0.94 \\
\hline & & Panicum & 2.41 & 0.58 & 8.35 & 27.3 & 1.10 & 4.04 & 0.81 \\
\hline & & Digitaria & 1.80 & 0.63 & 7.90 & 23.3 & 1.15 & 4.5 & 1.20 \\
\hline & & Sporobolus & 1.20 & 0.91 & 7.11 & 25.6 & 1.07 & 4.4 & 0.85 \\
\hline & & Iseilema & 1.67 & 0.68 & 8.10 & 29.3 & 1.35 & 5.2 & 1.02 \\
\hline \multirow[t]{6}{*}{2} & NF2 & & & & & & & & \\
\hline & & Cynodon & 0.65 & 0.66 & 28.6 & 59.7 & 0.99 & 3.1 & 3.14 \\
\hline & & Panicum & 0.82 & 0.49 & 22.3 & 67.2 & 0.85 & 5.1 & 3.37 \\
\hline & & Digitaria & 0.54 & 0.60 & 15.4 & 73.8 & 0.90 & 7.6 & 2.90 \\
\hline & & Sporobolus & 0.73 & 0.65 & 17.4 & 59.5 & 0.93 & 6.01 & 2.74 \\
\hline & & Iseilema & 0.47 & 0.59 & 21.9 & 57.9 & 1.04 & 6.2 & 4.00 \\
\hline \multirow[t]{6}{*}{3} & NF3 & & & & & & & & \\
\hline & & Cynodon & 0.75 & 0.46 & 10.9 & 25.6 & 1.27 & 0.8 & 2.2 \\
\hline & & Panicum & 0.62 & 0.43 & 13.0 & 22.8 & 1.12 & 0.79 & 3.5 \\
\hline & & Digitaria & 0.50 & 0.40 & 15.7 & 31.5 & 1.09 & 1.03 & 2.1 \\
\hline & & Sporobolus & 0.75 & 0.43 & 21.0 & 29.3 & 1.17 & 1 & 3.6 \\
\hline & & Iseilema & 0.66 & 0.40 & 17.0 & 20.0 & 1.44 & 1.29 & 3.4 \\
\hline \multirow[t]{6}{*}{4} & NF4 & & & & & & & & \\
\hline & & Cynodon & 0.61 & 0.36 & 32.7 & 44.0 & 1.09 & 9.9 & 1.2 \\
\hline & & Panicum & 0.21 & 0.33 & 33.1 & 59.1 & 0.91 & 12.0 & 1.4 \\
\hline & & Digitaria & 0.42 & 0.33 & 39.3 & 53.6 & 1.01 & 10.2 & 1.9 \\
\hline & & Sporobolus & 0.48 & 0.40 & 36.5 & 47.8 & 1.15 & 10.1 & 2.28 \\
\hline & & Iseilema & 0.38 & 0.48 & 27.7 & 47.6 & 1.03 & 10.2 & 1.9 \\
\hline \multirow[t]{6}{*}{5} & NF5 & & & & & & & & \\
\hline & & Cynodon & 1.78 & 0.58 & 19.3 & 34.0 & 1.10 & 9.7 & 2.09 \\
\hline & & Panicum & 1.14 & 0.54 & 13.2 & 12.5 & 1.00 & 8.9 & 1.4 \\
\hline & & Digitaria & 0.85 & 0.54 & 16.0 & 10.4 & 0.96 & 10.12 & 3.4 \\
\hline & & Sporobolus & 1.50 & 0.48 & 12.7 & 21.4 & 0.99 & 8.4 & 1.7 \\
\hline & & Iseilema & 1.57 & 0.63 & 9.7 & 23.3 & 0.96 & 12.7 & 2.8 \\
\hline \multirow[t]{6}{*}{6} & NF6 & & & & & & & & \\
\hline & & Cynodon & 0.97 & 0.95 & 11.8 & 68.7 & 0.91 & 2.72 & 2.3 \\
\hline & & Panicum & 1.00 & 0.81 & 16.2 & 40.7 & 0.90 & 2.54 & 1.55 \\
\hline & & Digitaria & 0.69 & 0.86 & 10.2 & 54.1 & 0.93 & 2.4 & 1.8 \\
\hline & & Sporobolus & 0.76 & 1.0 & 9.0 & 79.2 & 0.88 & 2.8 & 2.4 \\
\hline & & Iseilema & 1.23 & 1.0 & 9.0 & 54.1 & 1.10 & 2.2 & 1.8 \\
\hline \multirow[t]{6}{*}{7} & NF7 & & & & & & & & \\
\hline & & Cynodon & 1.32 & 0.66 & 14 & 15.3 & 1.16 & 3.5 & 1.05 \\
\hline & & Panicum & 0.94 & 0.77 & 14.3 & 15.5 & 1.06 & 3.8 & 1.4 \\
\hline & & Digitaria & 1.55 & 0.66 & 20.5 & 17.0 & 1.33 & 3.9 & 1.17 \\
\hline & & Sporobolus & 1.70 & 0.80 & 16.3 & 26.6 & 1.03 & 3.6 & 1.6 \\
\hline & & Iseilema & 1.88 & 0.84 & 18.5 & 34.4 & 1.30 & 3.35 & 1.5 \\
\hline \multirow[t]{6}{*}{8} & NF8 & & & & & & & & \\
\hline & & Cynodon & 0.88 & 0.54 & 11.7 & 33.8 & 0.76 & 2.6 & 1.4 \\
\hline & & Panicum & 0.82 & 0.48 & 11.6 & 23.9 & 0.78 & 3.3 & 1.44 \\
\hline & & Digitaria & 1.07 & 0.51 & 10.0 & 22.1 & 0.83 & 3.2 & 1.01 \\
\hline & & Sporobolus & 1.13 & 0.52 & 11.7 & 38.0 & 0.93 & 2.9 & 1.2 \\
\hline & & Iseilema & 1.31 & 0.44 & 9.6 & 50.6 & 0.91 & 2.8 & 1.48 \\
\hline \multirow[t]{6}{*}{9} & NF9 & & & & & & & & \\
\hline & & Cynodon & 3.23 & 0.95 & 24.7 & 68.2 & 0.99 & 2.42 & 2.23 \\
\hline & & Panicum & 2.76 & 0.66 & 18.6 & 27.3 & 0.83 & 2.26 & 1.20 \\
\hline & & Digitaria & 2.95 & 0.72 & 17.4 & 68.1 & 1.04 & 2.35 & 1.64 \\
\hline & & Sporobolus & 3.42 & 0.61 & 16.7 & 50.5 & 0.84 & 2.48 & 1.00 \\
\hline & & Iseilema & 2.01 & 0.89 & 16.1 & 65.5 & 1.03 & 2.53 & 1.14 \\
\hline \multirow[t]{6}{*}{10} & NF10 & & & & & & & & \\
\hline & & Cynodon & 1.51 & 0.51 & 48.0 & 34.1 & 0.91 & 3.0 & 2.31 \\
\hline & & Panicum & 1.25 & 0.49 & 22.4 & 20.2 & 1.00 & 2.1 & 2.5 \\
\hline & & Digitaria & 1.03 & 0.42 & 35.6 & 18.2 & 0.93 & 2.8 & 2.3 \\
\hline & & Sporobolus & 1.12 & 0.46 & 40.2 & 23.6 & 1.26 & 2.7 & 3.4 \\
\hline & & Iseilema & 1.35 & 0.54 & 33.0 & 22.7 & 1.05 & 2.6 & 2.57 \\
\hline
\end{tabular}


$15.5 \pm 1.15$ to $79.6 \pm 1.14 \mathrm{mgkg}^{-1}$ and $17.5 \pm 1.12$ to $49.6 \pm 1.16 \mathrm{mgkg}^{-1}$. Grass species studied, highest concentration of $\mathrm{Mn}$ was found in $S$. diander in the river bank soil and $D$. sanguinalis in non flooded soil. The grasses on river bank had higher Mn concentration in all the locations. This may be due to the heavy metal accumulation in the river bank by the flood during rainy season (Bhargava et al., 2009).

Correlation study: Metal uptake by grass plant was affected by several factors including metal concentrations in soils, soil $\mathrm{pH}$, organic matter content, types of plant etc. The correlation matrix of metal contents in grass species and some of the soil properties are given in the table.8. It is generally accepted that the metal concentration in soil is the dominant factor. Relationships between total metal contents in plants and surface soils, metals in plants were highly comparable with those of soil counterparts, although the gradient can differ between plant species. The result indicates that the pollution of the river had effect on the quality of river bank soil during the study period (Nouri et al., 2006).

Bio concentration factor: The generic $\mathrm{BCF}$ expressed in $\mathrm{mg} / \mathrm{kg}_{\text {dwt.plant }} / \mathrm{mg} / \mathrm{kg}_{\mathrm{dwt} \text {.soil }}$ have been used as indicator for the affinity for the accumulation of metals in plants. The mean BCF value varies widely with the type of metal and species of the grasses (Table 9). Irrespective of the grass species the BCF values of the metal in river bank follows the order $\mathrm{Zn}>\mathrm{Cu}>\mathrm{Mn}>\mathrm{Fe}>\mathrm{Pb}>\mathrm{Cd}>\mathrm{Ni}$. In the non-flooded soil the order remained same except that the BCF value of $\mathrm{Fe}$ was greater than $\mathrm{Mn}$. There was wide variation in the BCF values for Fe and Mn among the grass species and location i.e. river bank soil and non flooded soil. The BCF value of $\mathrm{Cd}$ was found to be highest in $I$. laxum. This indicated that among all the grass species I. laxum had high affinity for the accumulation of Cadmium followed by $\mathrm{Zn}, \mathrm{Pb}$ and $\mathrm{Cu}$ (Table 9 and 10). All grasses had equal affinity for $\mathrm{Ni}$. The higher the $\mathrm{BCF}$ values the higher the risk posed to the organism along the food chain (Mellem et al., 2009).

\section{Conclusion}

It was concluded from the study that the dominance of heavy metals follows a decreasing order of $\mathrm{Fe}>\mathrm{Mn}>$ $\mathrm{Ni}>\mathrm{Pb}>\mathrm{Cu}>\mathrm{Zn}>\mathrm{Cd}$. The values of $\mathrm{Pb}, \mathrm{Cd}, \mathrm{Cu}, \mathrm{Zn}$ progressively increased in river bank soil from Naraj to Komashasan indicating their enrichment by effluent discharge of the city towards lower stream of Cuttack city . Soil of river bank is more fertile with higher available Fe and Mn content. Among the grass species there was a wide variation in the heavy metal accumulation. Grass species I. laxum has the higher affinity for the accumulation of $\mathrm{Cd} \quad(0.85 \pm 0.05)$ followed by $\mathrm{Zn}, \mathrm{Pb}$ and $\mathrm{Cu}$. Kathajodi river stretch around the Cuttack city is greatly influenced by direct discharge of urban waste and effluent in the river and necessitates adequate strategies or management |planning to control the intrusion of pollutants in the river system and which can prevent contamination of fertile soil of river bank.

\section{REFERENCES}

Abbasi, S.A., Naseema Abbasi, Soni, Rajendra .(1998). Heavy metals in the environment, Mittal publications.

Abound, S.J. and Nandini, N. (2009). Heavy Metal Analysis and Sediment Quality Values in Urban Lakes. American Journal of Environmental Science, 5(6): 678-687.

Anglin-Brown, B., Armour-Brown, A. and Lalor, G.C. (1995). Heavy metal pollution in Jamaica 1: Survey of cadmium, lead and zinc concentrations in the Kintyre and Hope Flat districts. Journal of Environmental Geochemistry and Health, 17: 51-56.

AOAC, (2000). "Official methods of analysis". Journal of AOAC (Association of official analytical chemists) International.

APHA (2011). Standard Methods for Examination of Water and Wastewater. 20th Edn., American Public Health Association, Washington D. C., New York.

Barik, S.R. (2013). A study on heavy metals present in the sediments of Kathajodi river and to assess the impact on flora. M.Sc. Forestry Thesis, OUAT, Bhubaneswar.

Benavides, Maria P., Susanna M. Gallego, Maria L. Tomaro (2005) Cadmium Toxicity in Plants; Brazilian Journal of Plant Physiology, 17(1):21-34.

Bhargava, S. Saxena, U. and Bhragava, A.K. (2009). Some Microbiological Studies of Polluted Kali river water at Meerut. Biochem. Cell, Arch., 9: 155-156.

Black, C.A. (1965). Methods of Soil Analysis, Part 2 (ed.), American Society of Agronomy. Inc. Madison, Wisconsin, USA.

Burton, K.W. and John, E. (1977). A study of heavy metal contamination in the Rhondda Fawr, South Wales; $W a$ ter, Air, and Soil Pollution; 7:45-68.

Central Ground Water Board. (1995). Hydrogeological Atlas of Orissa. Bhubaneswar, India: Ministry of Water Resources, South eastern Region.

Das, J., Sahoo, R.K. and Sinha, B.K. (2002). Urban ground water pollution: A case study in Cuttack city, India. Ground Water Monitoring \& Remediation, 22(3): 95103.

De, S. and Mitra, A.K. (2002). Reclamation of mining generated wastelands at Alkusha- Gopalpur abandoned opencast project, Raniganj Coalfield, Eastern India, Environment geology, 43:39-47.

Fernandes, H. (1997). Heavy metal distribution in sediments and ecological risk assessment: role of diagenetic process in reducing metal toxicity in bottom sediments. Environmental pollution, 97:317-325.

Ghose, M. and Singh, S.P. (2005). A comparative study of cadmium phytoextraction by accumulator and weed species. Environmental Pollution,133:365-371.

Giguere, A., Campbell, P.G.C., Hare, L., Mc Donald, D.G. and Rasmussen, J.B. (2004). Influence of lake chemistry and fish age on cadmium, copper and zinc concentrations in various organs of indigenous yellow perch (Percaflavescens). Canadian Journal of Fisheries and Aquatic Sciences, 61: 702- 1716.

Gopal, G.V., Rajashekar, N. and Geetha, R. (2002). Lake Biodiversity of Macrophytic Plant Groups: A Case Study (Kukkarahalli Lake), In Proceedings of Symposium on Restoration of Lakes and Wetlands (Lake 2002), 
Center for Ecological Sciences, Indian Institute of Science, Bangalore.

Gupta, N., Yadav, K. K., Kumar, V. and Singh, D. (2013). Assessment of physicochemical properties of Yamuna river in Agra city. International Journal of Chemical Technology Research, 5(1): 528-531.

Jackson, M.L. (1973). Soil Chemical Analysis, Prentice Hall of India Pvt Ltd., New Delhi.

Klavins, M., Briede, A., Rodinov, V., Kokorite, I., Parele, E. and Klavina, I. (2000). Heavy metals in river of Lativa. The Science of the Total Environment, 262:175-183.

Lindsay, W.L. and Norvell, W.A. (1978). Development of a DTPA soil test for zinc, iron, manganese and copper. Soil Science Society of America Journal, 42:421-428.

Lokeshwari, H. and Chandrappa, G.T. (2006). Impact of heavy metal contamination of Bellandur Lake on soil and cultivated vegetation. Current Science, 91:622-627.

Macfarlane, G.R. and Burchett, M.D. (2000). Cellular distribution of $\mathrm{Cu}, \mathrm{Pb}$ and $\mathrm{Zn}$ in the grey mangrove Avicenniamarina (Frorsk.) Vierh. Aquatic Botany, 68:45-59.

Mellem, J., Baijanth, H. and Odhav, B. (2009). Translocation and Accumulation of $\mathrm{Cr}, \mathrm{Hg}, \mathrm{As}, \mathrm{Pb}, \mathrm{Cu}$ and $\mathrm{Ni}$ by Amaranthus dubius (Amaranthaceae) from Contaminated Sites. Journal of Environmental Science and Health, 44 (6) : 568-575.

Mohan, S.V., Nithila, P. \& Reddy, S.J. (1996). Estimation of Heavy Metal in Drinking Water and Development of Heavy Metal Pollution Index. Journal of Environmental Science and Health, 31(3): 283-289.

Nirmal Kumar, J.I Hiren Soni, and Rita N. Kumar (2006). Biomonitoring of selected freshwater macrophytes to assess lake trace element contamination: a case study of Nal Sarovar Bird Sanctuary, Gujarat, India, J. Limnol., 65(1): 9-16.

Nouri, J., Mahvi, A.H., Babaei, A. and Ahmadpour, E.
(2006). Regional pattern distribution of groundwater fluoride in the shush aquifer of Khuzestan county Iran Fluoride. Fluoride, 39(4): 321-325.

Pardo, R., Barrado, E., Perez, L. and Vega, M. (1990). Determination and speciation of heavy metal in sediments of the Pisuerga river. Water Research, 24(3):373-379.

Pascual-Barrera, A., Gold-Bouchot, G., Ceja-Moreno, V. and del Rýo-Garcý'a, M. (2004). Heavy metals and hydrocarbons in sediments from three Lakes from San Miguel, Chiapas, Mexico Bull. Environ. Contam. Toxicol., 73:762-769.

Prasad, B. and Kumar, S. (2008). Heavy Metal Pollution Index of Ground Water of an Abandoned Open Cast Mine Filled of the Water Quality of River Adyar, India. Bulletin of Environmental Contamination and Toxicology, 82(2):211-217.

Sharma, B.K. (2001). Environmental Chemistry-6th Revised Edition; GOEL Publishing House.

Singh, M., Muller, G. and Singh, I.B. (2002). Heavy metals in freshly deposited stream sediments of rivers associated with urbanization of the Ganga plain, India. Water, Air and Soil Pollution, 141:35-54.

Snedecor, G.W. and Cochran, W.G. (1967). Statistical Methods. 6th (ed.), Iowa State University, Ames, IA, USA., Pp.456.

Subbiah, B.V. and Asija, G.L. (1956). A rapid procedure for estimation of available nitrogen in soils. Current Science, 25: 259-260.

Upadhayay, A.K., Gupta, K.K., Surcar, J.K., Deb, M.K. and Mundhara, G. L. (2006). Heavy metals in freshly deposited sediments of the river Subernarekha, India: An example of lithogenic and anthropogenic effects. Environmental Geology, 50:397-403.

Yu, K.Y., Tasi, L.J., Chen, S.H. and Ho, S.T. (2001). Chemical binding of heavy metals in anoxic river sediments. Water Research, 35(7):4086-4094. 